\title{
ANALISIS YURIDIS TINDAK PIDANA KECELAKAAN LALU LINTAS BERAKIBAT KEMATIAN \\ (STUDI PENELITIAN DIWILAYAH HUKUM POLRES KOTA LHOKSEUMAWE)
}

\author{
Wahyu Maulana, Husni, Romi Asmara
}

\author{
Fakultas Hukum Program Studi Hukum Unimal \\ Komplek Kampus Bukit Indah, Jl.Jawa - Blang Pulo Kecamatan Muara Satu \\ P.O.Box 141 Lhokseumawe Mobile 082331239196 Faks. (0645) 40209
}

\begin{abstract}
The Law Number 22 of 2009 on Traffic and Transportation has given juridical regulation to traffic order. Numerous traffic accidents in the area of police station of Lhokseumawe city from 2016 to 2018 occurred due to the negligence of driver that cause casualties even death.

The study aimed to describe the criminal act of traffic accident fatality and the causes in the area of Police Station of Lhokseumawe. The study also attempted to examine the efforts of the traffic police of police station in Lhokseumawe to manage the criminal act of traffic accident fatality and the obstacles.

This study used qualitative methods with sociological juridical approach. Data obtained through library research and field research. Data analysis was conducted by using descriptive analysis.

Based on the results, it can be concluded that the criminal act of traffic accident fatality in the area of police station in Lhokseumawe is caused by negligence (culpa) of driver and noncompliance with the traffic laws. Majority of the accident is caused by one vehicle overtaking another vehicle. While the efforts to manage violations of traffic law was carried out preventively and repressively by the police station of Lhokseumawe. However, it might not be able to eliminate the violation directly but it can give a warning to the traffic violator.

To present an intact image of law to the public, it is suggested that the traffic police of Lhokseumawe city to handle traffic accidents using the strategy of single site (fixing sharp bend), mass action plans (coating the road surface), route action plans (improving traffic signs facilities), and area wide schemes (reducing vehicle speed on specific location), as well as improvements in the internal of police station in Lhokseumawe city.
\end{abstract}

Keywords: Juridical Analysis, Criminal Act, Accident, Traffic

\begin{abstract}
Abstrak
Keberadaan Undang - Undang Nomor 22 Tahun 2009 tentang Lalu Lintas dan Angkutan Jalan telah memberikan pengaturan yuridis terhadap tata cara dalam berlalu lintas. Banyaknya kasus kecelakaan lalu lintas diwilayah hukum polres lhokseumawe mulai dari tahun 2016 sampai 2018 terjadi akibat kelalaian pengguna pengendara kendaraan sehingga menimbulkan korban jiwa bahkan sampai berakibat kematian.

Penelitian ini bertujuan untuk memaparkan Tindak Pidana Kecelakaan Lalu Lintas Berakibat Kematian serta penyebabnya diwilayah Hukum Polres Lhokseumawe. Selanjutnya penelitian ini juga berupaya untuk menelaah usaha Satuan Polisi Lalu Lintas Polres Lhokseumawe dalam menanggulani Tindak Pidana Kelalaian Yang Menimbulkan Kecelakaan
\end{abstract}




\section{Jurnal Ilmiah Mahasiswa FAKULTAS HUKUM UNIMAL}

Analisis Yuridis....( Wahyu Maulana, Husni, Romi Asmara)

E-ISSN:

ISSN :

Volume 1 Nomor 1 Januari-April 2020 (halaman 1-19)

Lalu Lintas Ber akibat Kematian diwilayah Hukum Polres Lhokseumawe serta hambatan hambatannya.

Penelitian ini menggunakan metode kaulitatif dengan pendekatan yuridis sosiologis. Data diperoleh melalui kegiatan penelitian kepustakaan (Library research) dan penelitian lapangan (Field research).Analisis data dilakukan secara deskriptif (Descriptive analysis).

Berdasarkan hasil penelitian disimpulkan bahwa tindak pidana kecelakaan lalu lintas berakibat kematian diwilayah hukum Polres Kota Lhokseumawe tidak terlepas dari kelalaian (culpa) pengemudi kendaraan dan juga akibat ketidak patuhan hukum dari pengemudi dalam mentaati rambu-rambu lalu lintas. Yang mana kasus tertinggi kecelakaan diakibatkan mendahului kendaraan lain, adapun upaya - upaya penangulanggan pelanggaran lalu lintas yang dilakukan Sat Lantas Polres Kota Lhokseumawe yaitu dengan upaya preventif dan upaya represif, walaupun dalam hal demikian ini pada dasarnya tidak dapat menghilangkan pelanggaran secara langsung, akan tetapi dapat memberikan peringatan terhadap mereka yang telah melakukan pelanggaran.

Untuk dapat menghadirkan gambar hukum yang utuh ditengah masyarakat disarankan agar kiranya pihak Sat Lantas Polres Kota Lhokseumawe melakukan penanganan kecelakaan lalu lintas menggunakan strategi single site (memperbaiki jari- jari tikungan yang tajam), mass action plans (pelapisan permukaan perkerasan jalan), route action plans (perlengkapan fasilitas rambu- rambu jalan yang baik), dan area wide schemes (pengurangan kecepatan kendaraan pada lokasi tertentu), serta pembenahan dalam internal Polres Kota Lhokseumawe.

\section{Kata Kunci: Analisis Yuridis, tindak pidana, kecelakaan, lalu lintas}

\section{PENDAHULUAN}

Pengaruh era globalisasi disegala bidang kehidupan berbangsa dan bernegara di masa kini tidak dapat terelakkan, akibatnya hampir di semua negara terutama di negara berkembang merasakannya. Pengaruh ini berupa lajunya pertumbuhan penduduk dan perkembangan teknologi yang juga diikuti dengan perkembangan perekonomian masyarakatnya. Perkembangan perekonomian tersebut secara signifikan juga diikuti dengan meningkatnya mobilitas masyarakat dari suatu daerah ke daerah lain. Pada titik inilah peranan penting transportasi juga akan semakin dirasakan.

Setiap orang mempunyai hasrat untuk memenuhi kebutuhan hidup dan dinamika hidup, yang mengharuskan setiap manusia bergerak dari satu tempat ke tempat yang lain. Jarak tempat yang akan di tempuh oleh setiap manusia bervariasi sifatnya dan terkadang harus ditempuh dengan suatu perantara atau dengan suatu modal transportasi.

Kemajuan sistem transportasi semakin berkembang di seluruh wilayah Indonesia sehingga memerlukan penataan kembali terhadap hukum yang mengatur tentang lalu lintas agar tetap terciptanya ketertiban dan kenyamanan berlalu lintas. Transportasi mempunyai peranan penting dan strategis untuk memantapkan perwujudan wawasan nusantara, memperkukuh ketahanan nasional, dan mempererat hubungan antar bangsa dan dalam usaha mencapai tujuan nasioanal berdasarkan pancasila dan undang-undang dasar 1945. Peranan tersebut merupakan suatu peranan vital, sehingga dijadikan landasan pertimbangan dibentuknya undang-undang nomor 22 tahun 2009 Tentang Lalu Lintas dan Angkutan Jalan, (selanjutnya akan disingkat menjadi UULLDAJ) sebagai pengganti undang-undang nomor 14 tahun 1992 Tentang Lalu Lintas dan Angkutan Jalan yang dipandang tidak relevan lagi bagi masyarakat Indonesia (Soerjono Soekanto,1997). 


\section{Jurnal Ilmiah Mahasiswa FAKULTAS HUKUM UNIMAL}

Analisis Yuridis....( Wahyu Maulana, Husni, Romi Asmara)

E-ISSN:

ISSN :

Volume 1 Nomor 1 Januari-April 2020 (halaman 1-19)

Pembangunan yang dilaksanakan Indonesia adalah pembangunan di segala bidang yang merupakan suatu bagian dari proses modernisasi yang menciptakan kesejahteraan dan ketenteraman bagi masyarakat Indonesia. Pembangunan yang ada saat ini tentu saja memiliki kelebihan dan kekurangan dan salah satu kekurangan yang paling sering ditemui adalah tingginya tingkat kemacetan pada jam-jam sibuk.

Kemacetan merupakan salah satu dampak negatif dari semakin majunya pembangunan khususnya di bidang produksi kendaraan bermotor yang pada gilirannya menyebabkan semakin simpang siurnya lalu lintas jalan raya. Hal ini dikarenakan tidak berbandingnya jumlah kendaraan dengan jumlah ruas jalan yang pada akhirnya akan memungkinkan terjadinya kecelakaan lalu lintas dan menimbulkan rasa ketidaknyamanan bagi para pengguna jalan raya (Naning, 1983).

Salah satu penyebab tingginya tingkat kecelakan lalu lintas sendiri terjadi adalah kurangnya kesadaran masyarakat dalam hal ini pengemudi kendaraan dalam berkendara, misalnya tidak memperhatikan dan menaati peraturan lalu lintas yang sudah ada, tidak memiliki kesiapan mental pada saat mengemudi atau mengemudi dalam kondisi kelelahan, berada dalam pengaruh minuman keras, atau obat-obat terlarang (Soerjono Soekanto, 1990).

Kondisi ketidaksiapan pengemudi dalam berkendara memungkinkan terjadinya kecelakaan yang dapat membahayakan keselamatan pengguna jalan raya lainnya. Lengah, mengantuk, kurang terampil, tidak menjaga jarak, melaju terlalu cepat adalah contoh kesalahan pengemudi pada umumnya. Selain penyebab-penyebab kecelakaan lalu lintas yang telah diuraikan di atas,terjadinya kecelakaan lalu lintas di jalan raya juga dipengaruhi oleh faktor usia pengemudi (Soerjono Soekanto, 1990).

Selain itu dapat kita rasakan bahwabertambah ramainya pengguna jalan raya, kontruksi jalan yang kurang baik, kendaraan yang tidak memenuhi syarat, faktor kelalaian atau kecerobohan pengemudi tersebut tidak jarang menimbulkan korban, baik korban menderita luka berat atau korban meninggal dunia bahkan tidak jarang merenggut jiwa pengemudinya sendiri. Kenyataan yang sering ditemui sehari-hari adalah masih banyak pengemudi yang belum siap mental, terutama pengemudi kendaraan roda dua dan angkutan umum. Pengemudi tersebut saling mendahului tanpa memperdulikan keselamatan dirinya sendiri dan penumpang. Beberapa kecelakaan lalu lintas yang terjadi sebenarnya dapat dihindari bila pengguna jalan bisa berperilaku disiplin, sopan dan saling menghormati.

Dalam Pasal 24 UULLDAJ, menyebutkan bahwa:

1. Untuk keselamatan, keamanan, ketertiban, dan kelancaran lalu-lintas dan angkutan jalan, setiap orang yang menggunakan jalan, wajib :

a. Berperilaku tertib dengan mencegah hal-hal yang dapat merintangi, membahayakan kebebasan atau keselamtan lalu lintas, atau yang dapat menimbulkan kerusakan jalan dan bangunan jalan

b. Menempatkan kesadaran atau benda-benda lainnya di jalan sesuai dengan peruntukannya.

2. Pengemudi dan pemilik kendaraan bertanggung jawab terhadap kendaraan berikut muatannya yang ditinggalkan di jalan.

Adami Chazawi menyatakan kesalahan pengemudi mobil sering dapat disimpulkan dengan mempergunakan peraturan lalu lintas. Misalnya, ia tidak memberikan tanda akan membelok, atau ia akan mengendarai mobil tidak di jalur kiri, atau pada suatu persimpangan tidak memberikan proritas kepada kendaraan lain yang datang darisebelah kiri, atau menyetir mobil terlalu cepat melampaui batas kecepatan yang ditentukan dalam rambu-rambu di jalan yang bersangkutan (Adami Chazawi,2011). 
Tabel 1

\section{Jumlah Perkara Kecelakaan Lalu lintas di Polres Kota Lhokseumawe Dari Bulan Tahun 2016-2018.}

\begin{tabular}{|c|c|c|c|}
\hline \multicolumn{3}{|c|}{ Data Kasus Kecelakaan Lalu Lintas Diwilayah Hukum Polres } \\
Lhokseumawe \\
\hline Tahun & Jumlah Kasus & Luka-Luka & $\begin{array}{c}\text { Meniggal } \\
\text { Dunia }\end{array}$ \\
\hline 2016 & 438 & 361 & 77 \\
\hline 2017 & 277 & 208 & 69 \\
\hline 2018 & 107 & 231 & 69 \\
\hline
\end{tabular}

Sumber :Bagian Unit Laka Lantas Polres Kota Lhokseumawe .

Dari data diatas, banyaknya kasus kecelakaan lalu lintas mulai dari tahun 2016 sampai 2018 pada pengguna pengendara kendaraan sehingga menimbulkan korban, jumlah korban dalam suatu kecelakaan merupakan suatu hal yang tidak di inginkan oleh berbagai pihak, mengingat betapa sangat berharganya nyawa seseorang yang sulit diukur dengan sejumlah uang. Dan juga dengan banyaknya kasus kecelakaan di jalan raya setidaknya bisa menggambarkan cerminan minimnya kesadaranhukum bagi pengendara kendaraan dikarenakan masih banyak orang-orang mengemudi tidak tertib dan taat pada rambu-rambu lalu lintas.

Dari itu penulis tertarik melakukan penelitian dengan judul "Analisis yuridis Tindak Pidana Kecelakaan Lalu Lintas Berakibat Kematian (Studi Kasus wilayah Hukum Polres Kota Lhokseumawe)". Dengan banyaknya kasus tindak pidana kecelakaan lalu lintas di jalan raya yang menimbulkan korban, penulis sebisa mungkin mengetahui faktor penyebab kasus tindak pidana kecelakaan lalu lintas di jalan raya yang berakibat kematian. Oleh karena itu penyusun mengangkat tema ini untuk dikaji lebih dalam.

\section{METODE PENELITIAN}

Jenis penelitian yang digunakan dalam penelitian hukum ini adalah penelitian Kualitatif. Penelitian ini mengacu suatu proses yang mencoba untuk mendapatkan pemahaman yang lebih baik mengenai kompleksitas yang ada dalam interaksi manusiasertabermaksud untuk memahami fenomena tentang apa yang dialami oleh subjek penelitian, misalnya perilaku, persepsi, motivasi, dan secara holistic dengan cara deskriptif dalam bentuk kata-kata dan Bahasa pada suatu konteks khusus yang alamiah dan memanfaatkan berbagai metode alamiah dengan pendekatan yang digunakan dalam penelitian ini adalah pendekatan yuridis empiris atau yuridis sosiologis (sociological legal research).

\section{PEMBAHASAN}

\section{Penyebab Terjadinya Tindak Pidana Kecelakaan Lalu Lintas Berakibat Kematian Diwilayah Hukum Polres Kota Lhokseumawe}

Kecelakaan lalu lintas merupakan peristiwa yang tidak diduga dan tidak disengaja yang melibatkan kendaraan atau pengguna jalan lain yang dapat menimbulkan korban dan/atau kerugian harta benda. Kecelakaan lalu lintas bisa terjadi kapan saja dan dimana saja, tidak bisa 


\section{Jurnal Ilmiah Mahasiswa FAKULTAS HUKUM UNIMAL}

Analisis Yuridis....( Wahyu Maulana, Husni, Romi Asmara)

E-ISSN:

ISSN :

Volume 1 Nomor 1 Januari-April 2020 (halaman 1-19) luka berat atau kecacatan melainkan dapat mengakibatkan meinggal dunia (C.S.T, Kansil dan Christine S.T. Kansil, 1999).

Dapat dikatakan bahwa kecelakan dalam berlalu lintas bukanlah hal yang diinginkan oleh pelaku pengendara kendaraan dalam berlalu lintas, karena mengakibatkan kerugian baik harta maupun nyawa. Kerugian terjadi tidak hanya kerugian yang dialami korban, melainkan pelaku juga mengalaminya. BRIPKA Joko Nugroho menyatakan bahwa kecelakaan dalam berlalu lintas itu pada dasarnya diawali oleh adanya pelanggaran yang disebabkan oleh kelalaian dan human eror pengendara itu sendiri, walau dalam ketentuan terdapat kecelakaan yang disebabkan oleh kesengajaan, namun sampai saat ini tindak pidana kecelakaan lalu lintas terjadi karena kelalaian pengemudi kendaraan (Joko Nugroho, 2019).

BRIGADIR Edi Saputra selaku penyidik pembantu Unit Laka lantas menjelaskan bahwa dalam kasus kecelakaan lalu lintas yang telah ditangani tidak sedikit kecelakaan lalu lintas terjadi akibat saling mendahului kendaraan yang lain, yang dimana posisi pengemudi kendaraan pelaku terlalu mengambil jalur badan jalan yang berlawanan secara berdekatan sehingga mengakibatkan kecelakaan lalu lintas (Edi Saputra, 2019).

Dalam kaitannya dengan kecerobohan pengguna jalan, Wirjono Prodjodikoro menyatakan (Wirjono Prodjodikoro, 1967):

"Kesalahan pengemudi mobil sering dapat di simpulkan dengan mempergunakan peraturan lalu lintas. Misalnya, ia tidak memberikan tanda akan membelok, atau ia mengendarai mobil tidak di jalur kiri, atau pada suatu persimpangan tidak memberikan prioritas kepada kendaraan lain yang datang dari sebelah kiri, atau menjalankan mobil terlalu cepat melampaui batas"

Ashabul Jamil, S.Sos selaku Kabid Lalu Lintas dan Angkutan Dinas Perhubungan Kota Lhokseumawe menambahkan bahwa kurangnya pengalaman dan pengetahuan pengendara dapat menjadi penyebab kecelakaan dalam berlalu lintas (Ashabul Jamil, 2019).

Persyaratan teknis yang kaitannya dengan terjadinya kecelakaan, sepertiberkendara dengan kecepatan tinggi antara 80-100 km/jam dan berkendara dengan tujuan akhir yang jauh sehingga memakan waktu perjalanan yang lama dapat memberikan pengaruh terhadap pengemudi maupun kendaraannya:

a. Pengemudi berkurang konsentrasinya karena dalam waktu yang relatif lama tidak ada gangguan yang membutuhkan perhatiannya.

b. Pandangan bebas jauh kedepan akan menyebabkan ukuran jarak menjadi tidak lagi cocok dengan keadaan sehari-hari. Salah tafsir terhadap jarak dan kecepatan mungkin saja terjadi.

AIPTU Muhammad Rizal menjelaskan bahwa dari data kasus kecelakaan lalu lintas pertahunnya yang menjadi indikasi dasar penyebab kecelakaan yang paling dominan adalah faktor manusia, yaitu sebesar 93,7 \%, kemudian faktor kendaraan, faktor jalan, dan terakhir faktor lingkungan (Muhammad Rizal, 2019).

Faktor-faktor yang mempengaruhi kecelakaan lalu lintas di darat sangatlah beragam, mulai dari faktor pengemudi, faktor kendaraan dan faktor lingkungan. dari ketiga faktor tersebut, ternyata penyebab kecelakaan terbesar adalah karena kelalaian manusia jika diamati lebih jauh, maka kecelakaan di jalan lebih dari 81 persen akibat faktor manusia, banyaknya jumlah kendaraan bermotor yang beroperasi di jalan terkadang tidak diikuti dengan kesadaran pengguna jalan untuk mentaati rambu-rambu lalu lintas atau saling menghormati sesama pengguna jalan, 


\section{Jurnal Ilmiah Mahasiswa \\ FAKULTAS HUKUM UNIMAL}

Analisis Yuridis....( Wahyu Maulana, Husni, Romi Asmara)

E-ISSN:

ISSN :

Volume 1 Nomor 1 Januari-April 2020 (halaman 1-19)

ketidakdisiplinan dari pengguna jalan ini tentu dapat membahayakan pengguna jalan yang lain (Katalog BPS: 8301007.31, 2016).

AIPTU Muhammad Rizal menjelaskan bahwa kesadaran hukum dalam masyarakat kurang dalam mentaati aturan - aturan hukum, hal ini sangatlah penting dalam menjamin keselamatan dalam berlalu lintas, hal ini dapat dilihat bahwa kurangnya kesadaraan masyarakat dalam penggunaan jalur kendaraan sebagaimana yang dijelaskan dalam pasal 108 undangundang tentang lalu lintas yakni (Muhammad Rizal, Wawancara Tanggal 21 juni 2019):

\section{Pasal 108}

(1) Dalam berlalu lintas Pengguna Jalanharus menggunakan jalur Jalan sebelah kiri.

(2) Penggunaan jalur Jalan sebelah kanan hanya dapat dilakukan jika:

a. Pengemudi bermaksud akan melewati Kendaraan di depannya; atau

b. diperintahkan oleh petugas Kepolisian Negara Republik Indonesia untuk digunakan sementara sebagai jalur kiri.

(3) Sepeda Motor, Kendaraan Bermotor yang kecepatannya lebih rendah, mobil barang, dan Kendaraan Tidak Bermotor berada pada lajur kiri Jalan.

(4) Penggunaan lajur sebelah kanan hanya diperuntukkan bagi Kendaraan dengan kecepatan lebih tinggi, akan membelok kanan, mengubah arah, atau mendahului Kendaraan lain.

Selanjutnya beliau menjabarkan bahwa ada empat faktor yang sangat mempengaruhi dalam kecelakan lalu lintas yakni :

a. Manusia

b. Kendaraan

c. Jalan

d. Lingkungan.

Senada dengan hal tersebut Warpani berpendapat bahwa penyebab kecelakaan dapat dikelompokkan dalam empat unsur, yaitu : manusia, kendaraan, jalan, dan lingkungan. Keempat unsur tersebut dapat dijelaskan sebagai berikut (Warpani, 2002):

a. Manusia

Manusia sebagai pemakai jalan yaitu sebagai pejalan kaki dan pengendara kendaraan baik kendaraan bermotor maupun kendaraan tidak bermotor. Interaksi antara faktor manusia, kendaraan, jalan dan lingkungan sangat bergantung dari perilaku.

Manusia sebagai pengguna jalan menjadi hal yang paling dominan terhadap Kamseltibcar Lantas, hal ini sangat ditentukan oleh beberapa indikator yang membentuk sikap dan perilakunya di jalan raya berupa (Muhamad Ikhsan, 2009).

1) Mental

Mental dan perilaku yang membudaya dari pengguna jalan merupakan salah satu faktor utama yang sangat berpengaruh terhadap situasi lalu lintas. Etika, sopan - santun, toleransi antar pengguna jalan, kematangan dalam pengendalian emosi serta kepedulian pengguna jalan di jalan raya akan menimbulkan sebuah interaksi yang dapat mewarnai situasi lalu lintas berupa hasil yang positif seperti terciptanya keamanan, keselamatan dan

kelancaran lalu lintas maupun dampak negatif yang dapat menimbulkan

kesemrawutan, kemacetan, pelanggaran dan kecelakaan lalu lintas, sehingga mentalitas pengguna jalan merupakan suatu hal yang fundamental dalam mewujudkan situasi lalu lintas yang baik.

2) Pengetahuan 


\section{Jurnal Ilmiah Mahasiswa FAKULTAS HUKUM UNIMAL}

Analisis Yuridis....( Wahyu Maulana, Husni, Romi Asmara)

\section{E-ISSN:}

ISSN :

Volume 1 Nomor 1 Januari-April 2020 (halaman 1-19)

Setiap pengguna jalan wajib memahami setiap aturan yang telah dibakukan secara formal baik dalam bentuk Undang-Undang, Perpu, Peraturan Pemerintah, Perda dan aturan lainnya sehingga terdapat satu persepsi dalam pola tindak dan pola pikir dalam berinteraksi di jalan raya. Perbedaan tingkat pengetahuan dan atau pemahaman terhadap aturan yang berlaku mengakibatkan suatu kesenjangan yang berpotensi memunculkan permasalahan dalam berlalu lintas, baik antar pengguna jalan itu sendiri maupun antara pengguna jalan dengan aparat yang bertugas untuk melaksanakan penegakkan hukum di jalan raya.

3) Keterampilan

Kemampuan dalam mengendalikan kendaraan baik kendaraan bermotor maupun kendaraan tidak bermotor di jalan raya akan berpengaruh besar terhadap situasi lalu lintas, keterampilan mengendalikan kendaraan merupakan suatu keharusan yang mutlak demi keamanan, keselamatan, ketertiban dan kelancaraan lalu lintas baik bagi pengemudi / pengendara kendaraan tersebut maupun pengguna jalan lainnya.

b. Kendaraan

Kendaraan adalah satu alat yang dapat bergerak di jalan, terdiri dari kendaraan bermotor atau kendaraan tidak bermotor, Beberapa faktor yang dapat mempengaruhi situasi lalu lintas jalan raya yang melibatkan kendaraan dapat di bagi dalam 2 (dua) faktor utama yaitu (Muhamad Ikhsan, 2009):

1) Kuantitas Kendaraan

Pertambahan jumlah kendaraan bermotor setiap tahunnya menunjukan angka yang signifikan, hal ini merupakan sebuah manifestasi dari laju pembangunan nasional seiring dengan era globalisasi menuntut adanya percepatan dalam bidang perekonomian dan keamanan tuntutan perkembangan di sektor lainnnya yang mengharuskan adanya percepatan mobilitas untuk pencapaian hasil secara optimal. Persaingan ekonomi dan perindustrian dalam era pasar bebas memang sudah mulai dirasakan, dimana sekarang semakin banyaknya produsen kendaraan bermotor baik roda dua maupun roda empat memberikan hadiah, potongan harga bahkan dalam perkembangan terkini setiap dealer telah bekerja sama dengan persaingan usaha di bidang finasial yang tidak kalah ketatnya dalam bentuk kredit angsuran kendaraan bermotor mulai dari bunga angsuran ringan sampai dengan pemberian kemudahan uang muka yang sangat ringan bahkan ada yang mempromosikan tanpa uang muka.Setiap konsumen telah dapat memiliki kendaraan bermotor, persaingan usaha seperti ini memberikan kemudahan dan keringanan bagi masyarakat konsumen disamping itu apabila ditinjau dari aspek kesejahteraan hal ini memberikan kontribusi positif sehingga tidak dapat dielakan lagi dengan gencarnya promo serta kemudahan baik biaya maupun fasilitas menimbulkan dampak semakin tingginya kecepatan pertambahan jumlah kendaraan bermotor khususnya roda dua. Tingginya tingkat angka pertambahan kendaraan bermotor apabila ditinjau dari sektor keamanan dan keselamatan transportasi lalu lintas jalan raya menimbulkan dampak permasalahan yang cukup serius, apaliagi bila dibandingan dengan pertambahan panjang dan lebar ruas jalan yang sangat sedikit mengakibatkan semakin rumit dampak permasalahan yang ditimbulkan. Dapat dirasakan oleh seluruh pengguna jalan bahwa dari tahun ke tahun pertambahan lokasi dan ruas penggal jalan raya yang rawan kepadatan, kemacetan dan kesemrawutan semakin bertambah jumlahnya.

2) Kualitas Kendaraan

Kendaraan bermotor saat ini dirancang telah memper- timbangkan aspek keamanaan yang berhubungan dengan pemakai jalan dan angkutan barang dilain pihak juga 


\section{Jurnal Ilmiah Mahasiswa FAKULTAS HUKUM UNIMAL}

Analisis Yuridis....( Wahyu Maulana, Husni, Romi Asmara)

E-ISSN:

ISSN :

Volume 1 Nomor 1 Januari-April 2020 (halaman 1-19) lalu lintas. Kendaraan bermotor sebagai hasil produksi suatu pabrik, telah dirancang dengan suatu nilai faktor keamanan untuk menjamin keselamatan bagi pengendaranya. Kendaraan harus siap pakai, oleh karena itu kendaraan harus dipelihara dengan baik sehingga semua bagian mobil berfungsi dengan baik, seperti mesin, rem kemudi, ban, lampu, kaca spion, sabuk pengaman, dan alat-alat mobil.

Dengan demikian pemeliharaan kendaraan tersebut diharapkan dapat (Muhamad Ikhsan, 2009):

a). Mengurangi jumlah kecelakaan

b). Mengurangi jumlah korban kecelakaan pada pemakai jalan lainnya

c). Mengurangi besar kerusakan pada kendaraan bermotor

d). Kendaraan dapat tetap laik jalan.

Komponen kendaraan selalu dalam kondisi siap untuk dioperasionalkan secara baik sesuai dengan kebutuhan pada saat dikendarai/dikemudikan. Perbedaan pola pandang dan kepentingan dari setiap individu masyarakat pengguna jalan mengakibatkan adanya perubahan spesifikasi kendaraan bermotor sesuai dengan rancangan standard keamanan yang telah ditetapkan, dengan berbagai alasan pola pandang dan kepentingan banyak kendaraan dilakukan modifikasi yang mempengaruhi standard kelengkapan keamanan yang ada seperti penggantian spion sepeda motor standard menjadi spion modifikasi yang hanya memenuhi syarat formal tetapi tidak memenuhi syarat fungsi keamanannya bahkan banyak pula yang hanya memasang spion sebelah saja (satu spion) ataupun tidak melengkapi spion sama sekali.

Penggantian knalpot baik roda dua maupun roda empat dari standard menjadi modifikasi yang memiliki tampilan dan suara berbeda dan cenderung memekakan telinga bahkan dalam situasi tertentu dengan sengaja melepaskan knalpotnya, penggantian struktur pegas / suspensi kendaraan dengan ketinggian ekstrim baik yang dibuat sangat tinggi atau dibuat sangat rendah, hal ini menimbulkan dampak ketidak stabilan kendaraan serta mempengaruhi kelenturan dan sistem kejut dari fungsi pegas sehingga pada saat pengereman tidak dapat dikendalikan secara baik, masih banyak perubahan lain yang dilakukan sehingga mengakibatkan kualitas kendaraan bermotor tidak lagi memenuhi spesifikasi keamanan baik bagi pengemudi/pengendaranya maupun pengguna jalan lainnya termasuk lingkungan (Muhamad Ikhsan, 2009).

Selain perubahan secara fisik/modifikasi kendaraan, perawatan dan usia pakai kendaraan sering kali menjadi permasalahan terhadap keamanan dan keselamatan jalan raya, di lapangan kita sering menemukan asap knalpot yang mengeluarkan asap yang jauh melebihi batas gas buang emisi tidak saja menyebabkan polusi udara tetapi terhalangnya jarak pandang pengguna jalan lainnya, perawatan komponen mesin, rem, bam, dan komponen lain sering kali menjadi penyebab utama terjadinya suatu kemacetan, kesemrawutan bahkan kecelakan lalu lintas, kesadaran pengguna jalan terhadap kepedulian pada laik jalan kendaraan bermotornya merupakan salah satu faktor yang sangat penting dalam mewujudkan kamseltibcar lalu lintas (Muhamad Ikhsan, 2009).

c. Jalan

Jaringan transportasi jalan merupakan serangkaian simpul dan/atau ruang kegiatan yang dihubungkan oleh ruang lalu lintas sehingga membentuk satu kesatuan sistem jaringan untuk keperluan penyelenggaraan lalu lintas dan angkutan jalan, Jalan adalah jalan yang diperuntukkan bagi lalu lintas umum (Warpani, 2002).

d. Lingkungan

Lingkungan alam atau lingkungan binaan sangat mempengaruhi keselamatan lalu lintas. Bukit atau pohon yang menghalangi pandangan, tanjakan terjal, serta tikungan tajam merupakan 


\section{Jurnal Ilmiah Mahasiswa FAKULTAS HUKUM UNIMAL}

Analisis Yuridis....( Wahyu Maulana, Husni, Romi Asmara)

E-ISSN:

ISSN :

Volume 1 Nomor 1 Januari-April 2020 (halaman 1-19)

faktor alam yang perlu mendapat perhatian dalam pengelolaan lalu lintas. Cuaca buruk juga mempengaruhi keselamatan arus lalu lintas. Hujan yang deras atau berkabut menjadikan pandangan pengemudi sangat terbatas sehingga mudah sekali terjadi kesalahan antisipasi (Warpani, 2002).

Pada bagian ini, penulis pertama-tama akan memaparkan analisis terhadap penyebab terjadinya tindak pidana kelalaian yang menimbulkan kecelakaan lalu lintas berakibat kematian diwilayah hukum Polres Kota Lhokseumawe. Dari data awal penulis telah mendapatkan bahwa tahun 2016 terdapat 438 kasus kecelakaan lalu lintas yang menimbulkan korban luka mencapai 361 jiwa dan korban yang meninggal mencapai 77 jiwa, tahun 2017 terdapat 277 kasus kecelakaan lalu lintas yang menimbulkan korban luka 208 jiwa dan korban yang meninggal 69 jiwa, dan tahun 2018 terdapat 107 kasus kecelakaan lalu lintas yang menimbulkan korban luka 300 jiwa dan korban yang meninggal 69 jiwa.

Dari data diatas kita melihat bahwa kasus kecelakan lalu lintas dalam pertahunnya yakni mulai dari tahun 2016 sampai tahun 2018 mengalami penurunan hampir 50\%, namun angka kematian yang timbul dalam kasus kecelakaan lalu lintas tidak mengalami penurunan yang signifikan yang mana angka kematian tahun 2016 mencapai 77 jiwa, tahun 2017 mencapai 69 jiwa, dan tahun 2018 mencapai 69 jiwa.

Dalam kasus tertinggi kecelakaan yang menyebabkan kematian disebabkan oleh kelalaian manusiaitu sendiri yang mana disebabkan karena mendahului kendaraan lain tanpa memperhitungkan kemungkinan datangnya kendaraan dari arah depan atau berlawanan. Adapun yang dimaksud dengan penyebab kelalaian manusia antara lain, mengemudi kendaraan terlampau cepat, mengabaikan situasi lalu lintas, melamun, ditabrak dan atau menabrak kendaraan lain yang seringkali menjadi tabrakan beruntun, berlomba sepeda motor secara tidak resmi di jalan umum, lelah mengantuk, mengerem secara mendadak, menerobos lampu merah dan menelpon sambil mengemudi.

Wirjono Prodjodikoro menjelaskan bahwa terdapat beberapa kesalahan dari pengemudi yang dapat menyebabkan terjadinya kecelakaan yaitu sebagai berikut : Kesealahan pengemudi mobil sering dapat disimpulkan dengan mempergunakan peraturan lalu lintas. Misalnya, ia tidak memberikan tanda akan membelok, atau ia mengendarai mobil tidak di jalur kiri, atau pada suatu persimpangan tidak memberikan prioritas kepada kendaraan lain yang datang dari sebelah kiri, atau menjalankan mobil terlalu cepat melampaui batas kecepatan yang ditentukan dalam ramburambu dijalan yang bersangkutan (Wirjono Prodjodikoro, 2003).

AIPTU Muhammad Rizal selaku KANIT LAKA LANTAS Polres Lhokseumawe mengungkapkan bahwa banyaknya kasus kecelakaan lalu lintas sering terjadi akibat kelalaian daripada pengemudi kendaraan, baik kendaraan beroda dua maupun kendaraan beroda empat,hal ini disebabkan karena pengemudi kendaraan mendahului kendaraan lain tanpa memperhitungkan kemungkinan datangnya kendaraan dari arah yang berlawanan, sehingga kecelakaan dalam berlalu lintas tak dapat dihindarkan. Lalu masih sangat minimnya kesadaran pengemudi kendaraan roda dua dalam penggunaan perangkat keselamatan seperti helm yang memenuhi standar nasional sehinnga diduga menyebabkan kondisi yang bisa menimbulkan kematian pada pelaku maupun korban dalam kasus kecelakaan lalu lintas (Muhammad Rizal,2019).

Hal senada juga diungkapkan oleh BA Unit SAT LANTAS Polres Lhokseumawe BRIPKA Joko Nugroho selaku penyidik pembantu yang menyatakan bahwa timbulnya kecelakaan dalam berlalu lintas tidak terlepas dari human error (faktor manusia) dan kelalaian pengemudi kendaraan yang mana hampir dari $80 \%$ kasus kecelakan lalu lintas dan korban itu didominasi oleh kaum pelajar dan mahasiswa.Jugakendaraan besarseperti bus, truck dan kontainer, cenderung tidak mempedulikan kendaraan yang kecil-kecil. Akibatnya, banyak 


\section{Jurnal Ilmiah Mahasiswa FAKULTAS HUKUM UNIMAL}

Analisis Yuridis....( Wahyu Maulana, Husni, Romi Asmara)

E-ISSN:

ISSN :

Volume 1 Nomor 1 Januari-April 2020 (halaman 1-19) Mendahului dari sebelah kiri sangat banyak dilakukan oleh sepeda motor. Repotnya, sepeda motor sedemikianselain mendahului dari sebelah kiri dengan kecepatan tinggi, langsung memotong jalan dari kendaraan lain, untuk mendahului dari sebelah kiri lagi pada kendaraan di depan nyaris bagaikan akrobat yang berjalan zig-zag (Joko Nugroho,2019).

Berkaitan dengan tindak pidana kecelakaan lalu lintas akibat dari kelalaian diatur dalam pasal 310 UULLDAJ, disebutkan bahwa setiap orang yang mengemudikan kendaraan bermotor yang karena kelalaiannya mengakibatkan kecelakaan lalu lintas dengan:

1. Kerusakan kendaraan dan/atau barang, dipidana dengan pidana penjara paling lama 6 (enam) bulan dan/atau denda paling banyak Rp. 1.000.000,00 (satu juta rupiah).

2. Korban luka ringan dan kerusakan kendaraan dan/atau barang, dipidana dengan pidana penjara paling lama 1 (satu) tahun dan/atau denda paling banyak Rp. 2.000.000,00 (dua juta rupiah.

3. Korban luka berat, dipidana dengan pidana penjara paling lama 5 (lima) tahun dan/atau denda paling banyak Rp. 10.000.000,00 (sepuluh juta rupiah), dalam hal kecelakaan tersebut mengakibatkan orang lain meninggal dunia dipidana dengan pidana penjara paling lama 6 (enam) tahun dan/atau denda paling banyak Rp. 12.000.000,00 (dua belas juta rupiah).

Pasal 311: (1) Setiap orang yang dengan sengaja mengemudikan kendaraan bermotor dengan cara dan keadaan yang membahayakan bagi nyawa atau barang dipidana dengan pidana penjara paling lama 1 (satu) tahun atau denda paling banyak Rp. 3.000.000,00 (tiga juta rupiah). (2) Dalam hal perbuatan mengakibatkan kecelakaan lain dengan:

1. Kerusakan kendaraan dan/atau barang, pelaku dipidana dengan pidana penjara paling lama 2 (dua) tahun atau denda paling banyak Rp. 4.000.000,00 (empat juta rupiah).

2. Korban luka ringan dan kerusakan kendaraan dan/atau barang, dipidana dengan pidana penjara paling lama 4 (empat) tahun atau denda paling banyak Rp. 8.000.000,00 (delapan juta rupiah).

3. Korban luka berat, dipidana dengan pidana penjara paling lama 10 (sepuluh) tahun atau denda paling banyak Rp. 20.000.000,00 (dua puluh juta rupiah), dalam hal kecelakaan tersebut mengakibatkan orang lain meninggal dunia dipidana dengan pidana penjara paling lama 12 (dua belas) tahun atau denda paling banyak Rp. 24.000.000,00 (dua puluh empat juta rupiah).

4. Mengakibatkan orang lain meninggal dunia, pelaku dipidana dengan pidana penjara paling lama 12 (dua belas) tahun atau denda paling banyak Rp24.000.000,00 (dua puluh empat juta rupiah).

Pengemudi yang menghadapi bahaya cenderung bergerak reflek seperti mengerem atau menghindar ke arah yang lain. Dalam mekanisme reflek, rangsangan yang diterima langsung melewati sumsum tulang belakang dan diteruskan lewat efektor dengan sangat cepat melebihi gerak sadar yang harus melewati otak terlebih dahulu. Namun sebaliknya, pengemudi lainnya mungkin hanya dapat berteriak. Bahkan dalam kasus tertentu bisa saja malah menekan gas lebih dalam karena terkejut yang merupakan gerak reflek tak terkendali. (Joko Nugroho,Wawancara Tanggal 27 Mei 2019)

Disebutkan juga bahwa blind spot atau area penglihatan pengguna jalan adalah penyebab kecelakaan yang sering merenggut korban jiwa. Ini dapat dijelaskan dari sudut pandang biologis dan psikologis manusia, jika terjadi suatukondisi pada blind spot, maka yang muncul pada pengemudi tersebut adalah reaksi reflek atau keterkejutan (Sumarsono, 1994). 


\section{Jurnal Ilmiah Mahasiswa FAKULTAS HUKUM UNIMAL}

Analisis Yuridis....( Wahyu Maulana, Husni, Romi Asmara)

E-ISSN:

ISSN :

Volume 1 Nomor 1 Januari-April 2020 (halaman 1-19)

Hasil penulis memeriksa Berkas Acara Pemeriksaan Laporan Polisi Unit Laka Lantas

Polres Kota Lhokseumawe, penulis sendiri menemukan bahwa penyebab terjadinya tindak pidana kelalaian yang menimbulkan kecelakaan lalu lintas berakibat kematian antara lain :

a) Kecelakaan akibat mendahului kendaraan lain

b) Hilang kendali akibat laju kencang

c) Memotong jalan tanpa memperhatikan sekitar jalan

d) Tabrak pejalan kaki

e) Berkecepatan tinggi pada tikungan jalan

f) Berkecepatan tinggi pada persimpangan jalan

g) Memotong jalan tanpa memberi kode jalan

h) Akibat menghindari lubang jalan

i) Kelebihan muatan, kelalaian korban, dan tabrak lari.

Berdasarkan wawancara serta analisis dilapangan, penulis menyimpulkan bahwa tindak pidana kecelakaan lalu lintas berakibat kematian diwilayah hukum Polres Kota Lhokseumawe tidak terlepas dari kelalaian ( culpa) pengemudi kendaraan dan juga akibat ketidak patuhan serta kesadaraan hukum dari pengemudi dalam mentaati rambu-rambu lalu lintas. Yang mana kasus tertinggi tindak pidana kecelakaan lalu lintas berakibat kematian diwilayah hukum Polres Kota Lhokseumawe ialah kecelakaan akibat mendahului kendaraan lain, hal ini terjadi akibat pengemudi kendaraan mengambil tindakan saling mendahului tampa memperhatikan area sekitar, sehingga diduga menjadi faktor dalam hal terjadinya kecelakaan lalu lintas. Serta tingginya pelanggaran terhadap batas kecepatan yang seolah-olah tidak ada batasankecepatan yang diberlakukan hal ini terutama menjadi masalah pada jalan yang lalu lintas sedang sepi.Hal lain yang menyebakan terjadinya tindak pidana kecelakaan lalu lintas berakibat kematian diwilayah hukum Polres Kota Lhokseumawe juga tidak terlepas dari faktor internal Polres Kota Lhokseumawe. Sudah menjadi rahasia umum dalam penerbitan Surat Izin Mengemudi (SIM) diduga sering dimanfaatkan oleh oknum-oknum dalam internal Polres Kota Lhokseumawe, tidak jarang dalam proses penerbitan Surat Izin Mengemudi (SIM) tidak sesuai dengan kaedah dalam Undang-Undang No 22 Tahun 2009 Tentang Lalu Lintas dan Angkutan Jalan dan PERKAP No 9 Tahun 2012 Tentang Surat Izin Mengemudi, yang mana tidak diadakan pelaksanaan ujian praktik bagi peserta uji Surat Izin Pengemudi (SIM) serta pemahaman hukum dalam berlalu lintas seperti uji pengereman/keseimbangan, uji slalom/zig - zag, uji membentuk angka delapan, uji reaksi rem menghindar, dan uji berbalik arah membentuk huruf U (turn).Tingginya jumlah peserta uji Surat Izin Pengemudi (SIM) yang mengurus penerbitan SIM di Polres Kota Lhokseumawe diduga dimanfaatkan oleh oknum internal Polres Kota Lhokseumawe yang mana dalam proses penerbitan SIM tidaklah membutuhkan waktu lama atau yang dikenal dengan SIM Tembak dengan proses pembayaran yang tidak sesuai dengan kaidah norma yang berlaku, sehingga menjadi faktor terjadinya tindak pidana kelalaian yang menimbulkan kecelakaan lalu lintas berakibat kematian diwilayah hukum Polres Kota Lhokseumawe.

Kelalaian orang tua dalam memberikan kendaraan terhadap anak dibawah umur juga menjadi faktor dalam terjadinya tindak pidana kecelakaan lalu lintas berakibat kematian diwilayah hukum Polres Kota Lhokseumawe, yang mana seiring pertambahan daya pacu dalam persaingan perdagangan membuat perusahaan kendaraan memberikan kebijakan pembelian sepeda motor dengan sistem pengkreditan dengan suku bunga yang rendah sehingga memudahkan konsumen dalam membeli kendaraan, sehingga seringkali konsumen kendaraan memberikan kendaraan bagi anak yang dibawah umur. Penulis sendiri menemukan banyaknya korban maupun pelaku dari kecelakaan lalu lintas didominasi oleh kaum pelajar yang dibawah umur atau 18 (delapan belas) tahun kebawah. 
Jurnal Ilmiah Mahasiswa

FAKULTAS HUKUM UNIMAL
E-ISSN:

ISSN :

Volume 1 Nomor 1 Januari-April 2020 (halaman 1-19)

Hambatan Dan Upaya Unit Laka Lantas Polres Lhokseumawe Dalam Menanggulangi Terjadinya Tindak Pidana Kecelakaan Lalu Lintas Berakibat Kematian Diwilayah Hukum Polres Kota Lhokseumawe

AIPTU Muhammad Rizal menjelaskan dalam pelaksanaan upaya menanggulangi terjadinya tindak pidana kecelakaan lalu lintas berakibat kematianoleh Unit Laka Lantas Polres Lhokseumawe juga mempunyai beberapa kendala yang dialami antara lain (Muhammad Rizal,2019):

1. Faktor internal yang berasal dari kepolisian itu sendiri diantaranya adalah :

a. Terkendala pada jumlah personil yang dimiliki. Ini dibuktikan dengan masih banyaknya titik-titik rawan terjadinya pelanggaran lalu lintas yang belum terjaga oleh petugas satlantas. Karena daerah yang diprioritaskan adalah jalan protokol seperti daerah akses keluar masuknya kota seperti jalan simpang buloh (jalan arah masuk perkotaan) dan bundaran selat malaka (akses jalan keluar arah perkotaan). Selain itu petugas satlantas tidak hanya ditugaskan untuk menjaga dan mengatur lalu lintas tetapi juga mengamankan kegiatan masyarakat seperti contohnya demo.

b. Jumlah kendaraan patroli yang terbatas untuk melakukan kegiatan penegakan pelanggaran lalu lintas yang terjadi. Kondisi ini disebabkan karena banyaknya permintaan pengawalan dari instansi lain. Sehingga kendaraan untuk berpatroli menjadi berkurang dan menyebkan patroli tidak maksimal.

2. Faktor eksternal atau faktor dari luar yang dihadapi oleh pihak kepolisian dalam melaksanakan penegakan hukum terhadap pelanggaran lalu lintas adalah :

a. Kesadaran masyarakat yang masih rendah terhadap rambu-rambu lalu lintas dan tata tertib berlalu lintas serta pemahaman tentang keselamatan dan keamanan dalam berkendara di jalan. Tidak hanya itu kedisiplinan masyarakat dalam mengendari kendaraan masih sangat rendah dikarenakan mendahulukan kepentingan mereka sendiri

b. Minimnya Rambu Lalu Lintas/ Traffic Signdan Lampu Peringatan/ Warning Light, serta penanganan yang cenderung membutuhkan waktu lama apabila terdapat yang rusak .

c. Peningkatan pesat setiap tahunnya konsumen kendaraan, baik roda dua maupun roda empat .

Dalam hal penanganan pergantian alat peraga rambu lalu lintas, masalah yang dialami ini dikemukakan oleh Ashabul Jamil .S.Sos selaku Kabid Lalu Lintas dan Angkutan Dinas Perhubungan Kota Lhokseumawe yang mana "dalam hal penangangan pergantian alat peraga lalu lintas, kita melakukan proses pengadaan yang mana membutuhkan waktu satu bulan dikarenan pemesenan untuk alat rambu-rambu lalu lintas itu harus kebandung supaya sesuai dengan spect permintaan, dan proes rehab pada alat peraga lalu lintas juga membutuhkan waktu paling lama satu minggu, sesuai dengan kondisi kerusakan pada alat tersebut" (Ashabul Jamil,2019).

Dalam memperkuat kemampuan operasional penanggulangan perlu pula dipadukan 3 kemauan; political will, social will dan individual will. Kehendak pemerintah (pollitical will) dengan berbagai upaya perlu didukung oleh citra sosial (social will) melalui berbagai media melancarkan kehendak pemerintah, serta kekuatan yang tidak boleh dilupakan adalah human atau individual will, berupa kesadaran untuk patuh/taat pada hukum serta senantiasa berusaha menghindarkan diri untuk tidak berbuat kejahatan (Abintoro Prakoso, 2013).

Direktur Keamanan dan Keselamatan (DirKamsel) Korlantas Polri Brigjen Pol Chryshnanda Dwilaksana menyebutkan upaya penegakkan hukum di bidang lalu lintas tidak hanya sebatas menyalahkan atau mencari kesalahan, namun ada upaya-upaya yang menjadi poin penting tujuan penegakan hukum dijalan yaitu: 


\section{Jurnal Ilmiah Mahasiswa FAKULTAS HUKUM UNIMAL}

Analisis Yuridis....( Wahyu Maulana, Husni, Romi Asmara)

E-ISSN:

ISSN :

Volume 1 Nomor 1 Januari-April 2020 (halaman 1-19)

$<$ https://otomotif.kompas.com/read/2018/03/07/132200815/penegakan-hukum-lalu-lintasbangun-peradaban-di jalan?page=allAkses pada tangal 22 juni 2019).

1. Mencegah kecelakaan lalu lintas yang bermakna juga meningkatkan kualitas keselamatan dan menurunkan tingkat fatalitas korban kecelakaan.

2. Mencegah terjadinya kemacetan, demi mewujudkan keteraturan dalam berlalulintas yang aman, selamat tertib dan lancar.

3. Memberikan perlindungan, pengayoman dan pelayanan keamanan atau keselamatan, bagi pengguna jalan lainya, sehingga tetap terjaga tingkat produktifitas masyarakat.

4. Membangun budaya tertib dalam berlalu lintas, karena lalu lintas merupakan cermin budaya bangsa.

5. Menegakkan hukum merupakan bagian edukasi untuk mencerdaskan kehidupan berbangsa dan bernegara.

Upaya dalam meningkatkan keselamatan Lalu Lintas dan Angkutan Jalan.dapat dilakukan melalui (Direktorat Jenderal Perhubungan Darat, 2005):

1) Pelaksanaan pendidikan berlalu lintas sejak usia dini,

2) Sosialisasi tentang pentingnya keselamatan lalu lintas dan angkutan jalan,

3) Rencana aksi nasional keselamatan lalu lintas dan angkutan jalan melalui kampanye keselamatan lalu lintas dan angkutan jalan,

4) Peningkatan kapasitas jalan raya,

5) Memperbaiki jalan yang rusak yang dapat menyebabkan kecelakaan lalu lintas,

6) Memberi tanda atau rambu untuk mencegah terjadinya angka kecelakaan,

7) Perlengkapan rambu-rambu Lalu Lintas, dan

8) Mempersiapkan penyusunan umum nasional keselamatan Lalu Lintas dan Angkutan Jalan.

Untuk itu upaya penanggulangan pihak Sat Lantas Polres Lhokseumawe dalam mengurangi terjadinya tindak pidana kecelakaan lalu lintas berakibat kematian diwilayah hukum polres kota lhokseumawe, melaksanakan tugasnya dengan mengutamakan upaya preventif atau tindakan pencegahan dan represif atau menindak dengan mengkaji ulang suatu peristiwa yang terjadi sesuai dengan ketentuan yang diatur oleh undang-undang. Selain itu juga mengadakan patroli-patroli rutin dan operasi rutin.

Apabila operasi dan patroli rutin kurang maksimal maka pihak Sat Lantas Polres Lhokseumawe menggelar operasi khusus lalu lintas. Operasi khusus ini dengan melakukan razia kendaraan bermotor, baik razia kelengkapan kendaraan bermotor maupun razia kelengkapan surat kendaraan bermotor. AIPTU Muhammad Rizal menjelaskan bahwa upaya - upaya penangulanggan pelanggaran lalu lintas yang dilakukan Sat Lantas Polres Lhokseumawe yaitu dengan upaya preventif dan upaya represif, dengan penjelasan sebagai berikut: (Muhammad Rizal,2019)

\section{Upaya Preventif}

Adapun upaya-upaya preventif yang dilakukan pihak Sat Lantas Polres

Kota Lhokseumawe guna mencegah terjadinya pelanggaran lalu lintas yaitu ${ }^{1}$ : (https://tribratanews-polreslhokseumawe.com/baca/category/lantas,2019)

a. Pengaturan lalu lintas yang diartikan sebagai pemberitahuan kepada pemakai jalan, bagaimana dan dimana mereka dapat atau tidak bergerak atau berhenti terutama ada waktu kemacetan dan keadaan darurat. Dalam arti luas pengaturan lalu lintas meliputi semua aktifitas dari polisi dalam mengatur lalu lintas dijalan umum. 


\section{Jurnal Ilmiah Mahasiswa \\ FAKULTAS HUKUM UNIMAL}

Analisis Yuridis....( Wahyu Maulana, Husni, Romi Asmara)

E-ISSN:

ISSN :

Volume 1 Nomor 1 Januari-April 2020 (halaman 1-19)

b. Penjagaan lalu lintas adalah suatu kegiatan pengawasan lalu lintas pada tempat-tempat tertentu yang diadakan sesuai kebutuhan terutama bersifat pencegahan, perlindungan pelayanan terhadap pengguna jalan, bila menemukan pelanggaran lalu lintas maupun kecelakaan lalu lintas segera mengambil tindakan represif sesuai prosedur yang berlaku.

c. Sosialisasi atau kampanye untuk mematuhi peraturan lalu lintas melalui pemasangan spanduk-spanduk kushusnya diareal kawasan rawan kecelakaan.

d. Menghimbau kepada masyarakat khususnya para orang tua agar tidak memberikan kendaraan bagi anak dibawah umur .

e. Sosialisasi ke sekolah-sekolah seperti diadakannya Polsanak ( Polisi Sahabat Anak), PKS ( Police Goes to School), Taman Lalu Lintas, Saka Bhayangkara dan lain-lain.

f. Polmas atau pemolisian masyarakat adalah proses edukasi ditingkat komuniti guna membentuk budaya tertib lalu lintas.

g. Peningkatan giat rekayasa lalu lintas berupa perbaikan atau penyempurnaan marka jalan atau rambu-rambu lalu lintas serta sistem pengaturan arus lalu lintas yang diharapkan bisa mengurangi terjadinya pelanggaran marka jalan juga mencegah timbulnya kecelakaan lalu lintas.

h. Meningkatkan kegiatan Turjawali (peraturan, penjagaan, dan pengawalan patrol) terutama didaerah rawan pelanggaran dan rawan kecelakaan.

i. Menambal lubang pada badan jalan .

\section{Upaya Represif}

Adapun kegiatan Sat Lantas Polres Lhokseumawe dalam menaggulangi pelanggaran lalu lintas dengan cara represif adalah sebagai berikut

1) Tilang

Tilang adalah bukti pelanggaran. fungsi tilang itu sendiri adalahsebagai undangan kepada pelanggar lalu lintas untuk menghadiri sidang di pengadilan negeri, serta sebagai tanda bukti penyitaan atas barang yang disita oleh pihak kepolisian dari pelanggar.

2) Penyitaan

Penyitaan dilakukan karena pengendara kendaraan tidak membawa atau mempunyai surat-surat kelengkapan kendaraan bermotor dan surat izin mengemudi (SIM).

3) Teguran

Teguran dilakukan kepada pengendara kendaraan bermotor yang melakukan pelanggaran tetapi berjanji tidak akan melakukan pelanggaran lagi. Dilakukan dengan cara membuat surat pernyataan tertulis bahwa tidak akan melakukan pelanggaran.

Upaya ini diharapkan dapat menyelesaikan permasalahan dan juga mendatangkan rasa damai dalam masyarakat, walaupun dalam hal demikian ini pada dasarnya tidak dapat menghilangkan pelanggaran secara langsung, akan tetapi dapat memberikan peringatan terhadap mereka yang telah melakukan pelanggaran oleh masyarakat atau korban.

Kegiatan ini merupakan proses dan perwujudan pihak Satlantas Polres Lhokseumawe kepada masyarakat sebagai upaya untuk mengimplementasikan kepolisian dalam fungsi lalu lintas dimana kegiatan-kegiatan tersebut haruslah ditumbuh kembangkan dan dilaksanakan secara berkesinambungan dalam kebersamaan yang saling mendukung. Dengan adanya upaya diatas diharapkan apa yang ditujukan akan tercapai sesuai dengan tujuan kepolisian khususnya Satlantas Polres Kota Lhokseumawe.

Serta peranan pemerintahmemiliki tanggung jawab dalam upaya penanggulangan kecelakaan lalu lintas, upaya yang dapat dilakukan adalah melalui memengaruhi pola kehidupan masyarakat melalui usaha yang sistematik untuk membangun kesadaran masyarakat akan akibat 


\section{Jurnal Ilmiah Mahasiswa FAKULTAS HUKUM UNIMAL}

Analisis Yuridis....( Wahyu Maulana, Husni, Romi Asmara)

E-ISSN:

ISSN :

Volume 1 Nomor 1 Januari-April 2020 (halaman 1-19)

tindak pidana dan dampak penghukumannya. Misalnya, seorang terpidana akan dibatasi hak-hak politiknya selama beberapa tahun setelah selesai beberapa tahun menjalani proses hukumannya.

Juga peranan tokoh masyarakat bisa memengaruhi masyarakat sekitarnya melalui usahausaha membangkitkan jiwa kerohaniannya. Meskipun kegiatan ini telah dilakukan seringkali, namun kegiatan yang demikian harus dipandang perlu sebagai upaya untuk membangkitkan kesadaran akan sifat bahaya yang timbul dari tindak pidanana kelalaian yang menimbulkan kecelakaan lalu lintas berakibat kematian terhadap diri sendiri, keluarga, dan masyarakat. Sementara usaha lain yang bisa dilakukan oleh pihak lain yaitu pendidik adalah melakukan pendidikan karakter, dan membangun kesadaran kecerdasan moral dan nilai.

\section{KESIMPULAN}

Berdasarkan uraian dan hasil analisis yang telah diuraikan sebelumnya maka penulis dapat menarik kesimpulan dari hasil penelitian ini diantaranya: Penyebab tindak pidana kecelakaan lalu lintas berakibat kematian diwilayah hukum Polres Kota Lhokseumawe terjadi akibat kelalaian (culpa) pengemudi kendaraan dan juga akibat ketidak patuhan serta kesadaraan hukum dari pengemudi dalam mentaati rambu-rambu lalu lintas. sehingga menjadi faktor dalam hal terjadinya tindak pidana kecelakaan lalu lintas berakibat kematian. Yang mana dalam hal ini dari kasus tertinggi dalam kecelakaan lalu lintas terjadi akibat mendahului kendaraan lain. Serta dalam penerbitan Surat Izin Mengemudi (SIM) diduga sering dimanfaatkan oleh oknum-oknum dalam internal Polres Kota Lhokseumawe, tidak jarang dalam proses penerbitan Surat Izin Mengemudi (SIM) tidak sesuai dengan kaedah dalam Undang-Undang No 22 Tahun 2009 Tentang Lalu Lintas dan Angkutan Jalan dan PERKAP No 9 Tahun 2012 Tentang Surat Izin Mengemudi, yang mana tidak diadakan pelaksanaan ujian praktik bagi peserta uji Surat Izin Pengemudi (SIM) serta pemahaman hukum dalam berlalu lintas. sehingga menjadi faktor terjadinya tindak pidana kecelakaan lalu lintas berakibat kematian diwilayah hukum Polres Kota Lhokseumawe. Upaya - upaya penangulanggan pelanggaran lalu lintas yang dilakukan Sat Lantas Polres Kota Lhokseumawe yaitu dengan upaya preventif dan upaya represif, upaya ini diharapkan dapat menyelesaikan permasalahan dan juga mendatangkan rasa damai dalam masyarakat, walaupun dalam hal demikian ini pada dasarnya tidak dapat menghilangkan pelanggaran secara langsung, akan tetapi dapat memberikan peringatan terhadap mereka yang telah melakukan pelanggaran. Kegiatan ini merupakan proses dan perwujudan pihak Satlantas Polres Kota Lhokseumawe kepada masyarakat sebagai upaya untuk mengimplementasikan kepolisian dalam fungsi lalu lintas dimana kegiatan-kegiatan tersebut haruslah ditumbuh kembangkan dan dilaksanakan secara berkesinambungan dalam kebersamaan yang saling mendukung.

\section{SARAN}

Untuk memberikan kenyamanan dan keamanan dalam berlalu lintas serta mengurangi angka kematian yang diakibatkan oleh tindak kecelakaan lalu lintas berakibat kematian diwilayah hukum Polres Kota Lhokseumawe, hendaklah para pengguna jalan lebih disiplin dan mematuhi aturan lalu lintas dan memperhatikan sekitar jalan dan badan jalan, serta hendaklah para orang tua untuk tidak memberikan kendaraan pada anaknya yang dibawah umur. Dari hasil penelitian ini penulis menemukan bahwa banyaknya pelaku serta korban jiwa dalam tindak pidana kecelakaan lalu lintas berakibat kematian pada wilayah hukum Polres Kota Lhokseumawe berasal dari mereka yang berumur mulai dari umur 15 tahun sampai dengan umur 20 tahun . Serta perlulah agar kiranya Polres Kota Lhokseumawe melakukan pembenahan dalam internal Polres Kota Lhokseumawe ksususnya dalam penerbitan Surat Izin Mengemudi (SIM), agar terhindar dari dugaan praktik pungli yang diduga dilakukan oleh segelintir oknum internal 


\section{Jurnal Ilmiah Mahasiswa}

FAKULTAS HUKUM UNIMAL
Analisis Yuridis....( Wahyu Maulana, Husni, Romi Asmara)

E-ISSN:

ISSN :

Volume 1 Nomor 1 Januari-April 2020 (halaman 1-19)

Polres Kota Lhokseumawe agar dalam penerbitan Surat Izin Mengemudi (SIM) dilalui dengan mekanisme yang diatur dalam kaidah norma hukum yang berlaku, sehingga menciptakan pengemudi yang telah layak memenuhi persyaratan kelulusan ujian praktik Surat Izin Mengemudi (SIM). Untuk menghadirkan hukum yang utuh ditengah masyarakat maka perlu kiranya pihak Sat Lantas Polres Kota Lhokseumawe melakukan penanganan lokasi kecelakaan yang berguna untuk mengurangi angka kecelakaan dan korban kecelakaan serta berkurangnya biaya kecelakaan berdasarkan pertimbangan keselamatan lokasi lalu lintas yang dilakukan oleh pengguna jalan sendiri atau instansi- instansi terkait. Untuk penanganan kecelakaan lalu lintas dapat digunakan 4 (empat) strategi dasar, yaitu :single site (memperbaiki jari- jari tikungan yang tajam), mass action plans (pelapisan permukaan perkerasan jalan), route action plans (perlengkapan fasilitas rambu- rambu jalan yang baik), dan area wide schemes (pengurangan kecepatan kendaraan pada lokasi tertentu), serta pembenahan dalam internal Polres Kota Lhokseumawe. 
E-ISSN:

ISSN :

Volume 1 Nomor 1 Januari-April 2020 (halaman 1-19)

\section{DAFTAR PUSTAKA}

Abdussalam, 2006, Prospek Hukum Pidana Indonesia, Restu Agung, Jakarta. Abintoro Prakoso, 2013, Kriminologi dan Hukum Pidana, Laksbang Grafika, Yogyakarta.

Achmad Ali, 2002, Menguak Tabir Hukum (Suatu Kajian Filosofis Dan Sosiologis), PT. Toko Gunung Agung Tbk. Jakarta.

Adami Chazawi, 2011, PelajaranHukum Pidana I, Raja GrafindoPersada, Jakarta. Bahder Johan Nasution, 2005, Hukum Kesehatan Pertanggungjawaban Dokter,

Rineka Cipta, Jakarta.

Bambang Poernomo, 1982, Asas-asas Hukum Pidana, Ghalilea Indonesia, Yogyakarta.

Chaerudin, Syaiful Ahmad Dinar, Syarif Fadillah, 2008. Strategi Pencegahan Dan Penegakan Hukum Tindak Pidana Korupsi, Refika Editama, Bandung.

C.S.T.Kansil\&Cristhine Kansil, 2004, Pokok-Pokok Hukum Pidana, Pradya Paramita, Jakarta. Jakarta. , 1999, Disiplin Berlalu Lintas Dijalan Raya, Aneka Cipta,

D.Schaffmeiste, N.Keijzer dan E.PH.Sutorius, 2007, Hukum Pidana, Citra Aditya Bakti, Bandung.

Direktorat Jenderal Perhubungan Darat, 2005, Manajemen Kampanye keselamatan Lalu lintas dan angkutan jalan, Jakarta, DEPHUB RI.

Fakultas Hukum Universitas Malikussaleh, 2016, Panduan Penulisan Tugas Akhir Skripsi, Unimal Press, Lhoksumawe.

H.B. Sutopo, 1998, Metodologi Penelitian Hukum Kualitatif Bagian II, UNS Press, Surakarta.

Hobbs, F. D, 1995, Perencanaan Dan Teknik Lalu Lintas. Edisi kedua, Gadjah Mada University Press, Yogyakarta.

Katalog BPS: 8301007.31, 2016, Statistik Transportasi DKI Jakarta 2016, BPS Provinsi DKI Jakarta, 2016.

Leksmono Suryo Putranto, 2007, Rekayasa Lalu Lintas, PT.Indeks. Jakarta.

Leden Marpaung, 2005, Asas, Teori, Praktik Hukum Pidana, Sinar Grafika, Jakarta

Moeljatno, 2008, Asas-asas Hukum Pidana, Rineka Cipta, Jakarta.

Moeljatno, 1993, Perbuatan Pidana dan Pertanggung jawaban Dalam Hukum Pidana, Bina Aksara, Jakarta. 
Jurnal Ilmiah Mahasiswa

FAKULTAS HUKUM UNIMAL
Analisis Yuridis....( Wahyu Maulana, Husni, Romi Asmara)

E-ISSN:

ISSN :

Volume 1 Nomor 1 Januari-April 2020 (halaman 1-19)

Moh. Nadzir, 1988, Metode Penelitian, Ghalia Indonesia, Jakarta.

Naning, 1983, Pengertian Pelanggaran Lalu Lintas, C.V Rajawali, Jakarta.

Nasution. S, 2008, Metode Research dan Penelitian Ilmiah, Bumi Aksara, Jakarta Peter Mahmud Marzuki, 2005, Penelitian Hukum, Cet.IX, Kencana Prenada Media Group.

R. Soesilo, 1996, Kitab Undang-undang Hukum Pidana (Serta Komentar- Komentarnya Lengkap Pasal Demi Pasal), Sukabumi: Bogor-Politeia.

Ramdlon Naning, 1983, Menggairahkan kesadaran Hukum Masyarakat Dan Disiplin Penegak Hukum Dalam Lalu Lintas, Bina Ilmu, Surabaya.

Subekti, 2011, Aneka Perjanjian, Citra Aditya Bakti, Bandung.

Suharsimi Arikunto, 2002, Prosedur Penelitian Suatu Pendekatn Praktek, Rineta Cipta, Jakarta.

Sumarsono, 1994, Penegakan Hukum Lalu-Lintas dan Angkutan Jalan Dalam Rangka Peningkatan Disiplin Berlalu-lintas, Alfabeta, Bandung.

Soerjono Soekanto, 2004, Faktor-Faktor Yang Mempengaruhi Penegeakan Hukum Cetakan Kelima, Raja Grafindo Persada, Jakarta

1997, Kesadaran Hukum dan Kepatuhan Hukum, CV. Rajawali, Jakarta.

1990, Polisi dan Lalu Lintas Analisis Menurut Sosiologi Hukum, CV. Mandar Maju, Bandung.

W.J.S.Poerwadarminta, 1993, Kamus Umum Bahasa Indonesia, Balai Pustaka, Jakarta.

Warpani, 2002, Pengelolaan Lalu Lintas dan Angkutan Jalan, ITB, Bandung, 2002. Wirjono Prodjodikoro, 2003, Asas-Asas Hukum Pidana di Indonesia, Refika

Aditama, Bandung.

1967, Tindak-Tindak Pidana Tertentu Di Indoneia, Eresco, Jakarta.

Zainuddin Ali, 2014, Metode Penelitian Hukum, Sinar Grafika, Jakarta.

Republik Indonesia, Undang- Undang Nomor 22 Tahun 2009 Tentang Lalu Lintas dan Angkutan Jalan.

Republik Indonesia, Peraturan Kepala Kepolisian Negara Republik Indonesia Nomor 9 Tahun 2012 Tentang Surat Izin Mengemudi.

Muhamad Ikhsan,2009, Dalam Makalah Seminar Lalu Lintas Dan Permasalahannya, Yogyakarta.https://library.binus.ac.id/eColls/eThesisdo c/Bab2DOC/2014-1-01380 SP\%20Bab2001.doc diakses pada tanggal 21 juni 2019. 
J I M

Jurnal Ilmiah Mahasiswa

FAKULTAS HUKUM UNIMAL
Analisis Yuridis....( Wahyu Maulana, Husni, Romi Asmara)

E-ISSN:

ISSN :

Volume 1 Nomor 1 Januari-April 2020 (halaman 1-19)

Penegakan Hukum Lalu Lintas, Bangun Peradaban di Jalan, <https://otomotif. kompas.com/read/2018/03/07/132200815/penegakan-hukum-lalu-lintas- bangunperadaban-di jalan ? page=all/. Akses pada tangal 22 juni 2019.

https://tribratanews-polreslhokseumawe.com/baca/category/lantas, diakses pada tanggal 21 juni 2019. 